Chapter Title: The positive and fundamental value of excellence in universities Chapter Author(s): Alain Beretz

Book Title: Places of Engagement

Book Subtitle: Reflections on Higher Education in 2040 - A Global Approach

Book Editor(s): Armand Heijnen and Rob van der Vaart

Published by: Amsterdam University Press

Stable URL: https://www.jstor.org/stable/j.ctvfjd0xs.6

JSTOR is a not-for-profit service that helps scholars, researchers, and students discover, use, and build upon a wide range of content in a trusted digital archive. We use information technology and tools to increase productivity and facilitate new forms of scholarship. For more information about JSTOR, please contact support@jstor.org.

Your use of the JSTOR archive indicates your acceptance of the Terms \& Conditions of Use, available at https://about.jstor.org/terms

CC This content is licensed under a Creative Commons Attribution-NonCommercial-NoDerivatives

(C) $\$ \Theta 9$ 4.0 International License (CC BY-NC-ND 4.0). To view a copy of this license, visit

BY NC ND https://creativecommons.org/licenses/by-nc-nd/4.0/.

Amsterdam University Press is collaborating with JSTOR to digitize, preserve and extend access to Places of Engagement 


\title{
The positive and fundamental value of excellence in universities
}

\author{
Alain Beretz
}

Bert van der Zwaan, as chair of the League of European Universities (LERU), has often been involved in promoting the excellence of European research universities. In this demanding task, Bert has demonstrated his personal qualities of leadership, determination, and diplomacy. This paper is a small tribute to his activities in that domain.

The quest for excellence is very often associated with competition. Speaking about competition in the academic sector can, according to the context or background, be considered either a basic value or a major problem. Academic competition has always been at the heart of academic life and is based on the central importance of competition in the research process. Researchers have always tried to be the first to find and the first to open new pathways of knowledge. However, I am not sure that the way the word competition is used nowadays really describes this strive for excellence or this quest (Beretz 2016). In fact, there are two types of academic competition: the first one is market-oriented, i.e. you compete for a 'market' such as student registration fees, or some sources of private or even public money. In this type of market-driven competition, higher education is treated as a commodity. The second type of competition is centrally concerned with the quest for excellence and does not involve any aggressive or predatory behaviour. In this meaning of the word, competition is more a basic value - a non-interested, unbiased quest for excellence. Two brief examples show that implementing excellence schemes is not straightforward and can lead to misunderstandings and tensions.

In France, universities are under a uniform rule regime, with only a single set of regulations serving a wide diversity of 
situations. For example, the budget allocated to universities is based on a single algorithm, whatever the specific profile of the university. Even the basic notion of 'research university' is seen as not acceptable by some unions or civil servants, precisely because it introduces diversity into the system. Following the model adopted earlier in Germany, France has launched a so-called 'excellence initiative' of pushing forward some ten world-level campuses. This has led to some misinterpretation and fears. If universities failed the competition, this failure was too often attributed to the supposed inequality and biased structure of the competition itself. The basic principle of such a competition is also being questioned by some unions, which believe it would open the door to a biased, unequal public academic system. In fact, the quest for excellence without underlying values is useless. When implementing excellence schemes of any kind, one too often points out the 'winners' and 'losers', and this perspective ends up yielding much frustration and opposition. To avoid this frustration, it is necessary that these schemes only come on top of a global academic system that ensures that all types of academic enterprises are funded and sustained at the level that they deserve. This way, the 'winners' do not steal anything from the 'losers'; they just receive an extra reward for their specific excellence, whatever the scale.

In the European agenda on research, one can always feel a tension between excellence and widening. The quest for excellence in research, which is a cornerstone of the European Union's Framework Programme, is sometimes seen to lead to an increase of inequalities in research and innovation, with certain countries lagging behind the rest of Europe in terms of scientific output. We need to avoid widening this gap, and those two notions should urgently be reconciled in order to avoid a loss of value and to ensure that the impact of EU investments in research and innovation is maximized. One possible solution would be to address this issue as a core dimension of the European Research Area, where the funding of excellence and the support of widening activities should be complementary and coordinated. 
Opponents of the concept of excellence in universities often base their position on the assumption that excellence schemes will open or increase gaps, leading to segregated levels of research funding and biased student recruitment. They also assume that focusing on excellence will lead to supporting only large, world-class institutions and leave behind smaller ones, creating a first and second-tier system of universities based on their global research performance. Similarly, one could fear the creation of very stratified, watertight compartments of excellence within one single university. In all these aspects, excellence can unfortunately become a dividing force, which we can therefore name exclusive excellence. This is, of course, not my belief. But this is not only a matter of belief but of facts: excellence can be both distributive and inclusive. First, excellence can be a driving force with a strong spillover effect. When I was president of the University of Strasbourg, we were proud to succeed in the very competitive 'Excellence Initiative'. This led some teams in the university to receive significantly more support than others.

When presenting our first assessment report to the international jury, we demonstrated that we were able to avoid the 'more money, more problems' syndrome or the 'ivory tower' syndrome. We showed that the successful implementation of the initiative itself had been a major factor in increasing corporate identity and pride. This success brought all actors together, while it could have been a violently dividing agent. In fact, we had achieved inclusive excellence. In this state of mind, the excellent teams and structures can 'radiate excellence' towards the rest of the institution, and excellence can trickle down far beyond what is sometimes defined as an excellence perimeter. This can help to deepen a culture of excellence and spread group work across the various areas of the university (Bennetot Pruvot \& Esterman 2016). Thus, inclusive excellence is not a race to the bottom; it is inclusion without dilution. It can combine the highest quality standards with a true sense of sharing and solidarity or 'esprit de corps'. 
Finally, excellence is not only the privilege of large, world-class universities. Observations of the results of excellence schemes in Germany and France, or at the European level with the European research council, demonstrate that pockets of excellence are to be found in a wide array of institutions and that excellence is not just concentrated in some champion institutions. The notion of distributed excellence has been used to describe this situation (KRASP and HRK 2017).

Universities would appear to have nothing to do with football. However, this metaphor may reveal a parallel between both worlds, as it has been said that the European Research Council was started as a 'Champion's League of Europe'. This prediction came true; but one should remember that those teams playing the Champion's League also have a responsibility to set an example, so that smaller clubs play the game with pleasure while respecting the rules. In his book, Bert van der Zwaan points out that 'there is an urgent need for a less corporate approach to managing universities' (Van der Zwaan 2017). Maybe negative perceptions of academic excellence are caused by such a corporate approach whereas, when considered a fundamental academic value, excellence may be a positive driving force that sets examples and provides less-biased incentives and rewards. In academia, excellence is not a nasty word, or at least it should not be. Excellent universities are not there to crush the competition. They have a strong responsibility to be flagships, to act as beacons and examples. This is 'what universities are for', as was stated in one of the founding papers issued by the League of European Research Universities, that Bert has so elegantly and efficiently chaired (Boulton \& Lucas 2008). This is the legacy that Bert has transferred to us and that we can all be thankful for. 


\section{Bibliography}

Enora Bennetot Pruvot and Thomas Esterman, DEFINE Thematic Report: Funding for Excellence (Brussels: European University Association, 2016). Available from: http://www.eua.be/Libraries/publication/DEFINE_Funding_for_Excellence.pdf?sfvrsn=4 [Accessed: 12 March 2018].

Alain Beretz, 'Competition as an engine for progress: a normal rule for universities', in Legacy of Charles IV: Education and Academic Freedoms, Innovation and Open Society ed. Veronika Hunt Safránková (Prague: Karolinum, 2016).

Geoffrey Boulton and Colin Lucas, What are universities for?, LERU position paper (Brussels: League of European Research Universities, 2008). Available from: https://www.leru.org/files/ What-are-Universities-for-Full-paper.pdf [Accessed: 12 March 2018].

KRASP and HRK, Distributed Excellence. A discussion paper by the German and Polish Rectors' Conferences on elements of the future research, education and innovation funding of the EU after 2020 (2017). Available from: https://www.hrk.de/ fileadmin/redaktion/hrk/o2-Dokumente/Distributed_Excellence_HRK-CRASP_11_2017.pdf [Accessed:12 March 2018].

Bert van der Zwaan, Higher Education in $2040-A$ Global Approach (Amsterdam: Amsterdam University Press, 2017). 